\title{
Optimizing Golden Age Through Parenting in Saqo Kindegarten
}

\author{
Wiwin Yulianingsih ${ }^{1, *}$, Heryanto Susilo ${ }^{1}$, Rivo Nugroho $^{1}$, Soedjarwo ${ }^{1}$ \\ ${ }^{I}$ Department of of Non Formal Education, Faculty of Education, Universitas Negeri Surabaya, Surabaya, Indonesia \\ "Corresponding author.Email: wiwinyulianingsih@unesa.ac.id
}

\begin{abstract}
The aim of the community service to optimize the golden age through parenting activities for parents in SAQO Early Childhood Education Institution Kraksaan, Probolinggo aims to improve education carried out by families by utilizing the resources available in the family and the environment in the form of independent learning activities. The method of implementing the parenting education program at SAQO Early Childhood Education Institution was a participatory, demonstration, and assignment method with a share and care approach. It was carried out through the stages of the identification process of parents' learning needs. Parents understand the importance of parenting programs for child development. The results obtained are 1). Parents understand the golden age of children. 2). Parents understand the importance of parenting styles for early childhood. 3). Availability of facilities and infrastructure used by presenters to deliver parenting programs to parents, 4). Parents were very enthusiastic about participating in the program activities provided by the team - proven by $90 \%$ of the number of parents' attendance. 5). During the delivery of material, parents actively and responsively responded to the material provided. 6). Teachers and parents expect that the team can provide an advanced material presentation on other occasions. With this parenting education, parents receive new knowledge and experience. Therefore, parents could take care of their children positively according to children's development stage

Keywords: the golden age, parenting styles, parenting education
\end{abstract}

\section{INTRODUCTION}

Good parents are usually defined as parents who express love and affection, listen to children, create safe feeliing for children, guide them with rules, boundaries, and limitation, praise children, avoid criticism by focusing on behavior, always be consistent, take a role as a model, take time for children and provide spiritual understanding[1] Parenting is an educational effort carried out by the family by utilizing the resources available in the family and environment in the form of independent learning activities. Parenting education as a forum for communication between parents and children has a purpose and invites parents to jointly provide the best nurturing approach for their children. Parenting is a learning process of nurturing interactions between parents and children which includes activities to give instructions, to feed, to provide clothes, protect children as they grow. Children are formed through a development in the learning process. In the initial development period, children will exhibita safe feeling regarding their families when their needs are fulfilled by the environment, especially in the context of the family[2]. Most parents consider their involvement in children's education only to bear costs, provide infrastructure and various other material needs. In the context of education, parental involvement must encompass a broader scope than mere financing. The involvement of parents includes all approaches and support towards facilitating and guiding learning and the quality of education for children. Among other things, the term parenting refers to the interaction and communication of parents with their children[3]. Therefore, it requires an approach to increase the knowledge and skills of parents so that they can provide support to early childhood more optimally through parenting empowerment programs where children acquired early childhood education program both in kindergarten or playgroup.

The facts obtained in the field observation indicate that many institutions still provide limited services, particularly in rural areas. Most of these institutions deal with children with low socio-economic background, therefore contributions in the form of funds provided by parents are also limited. As a result, the ability of institutions to provide decent facilities and infrastructure is limited. Likewise, the fees given to instructors and the monthly operational costs cannot be optimized. Low parenting education has an impact on their limited knowledge about the importance of the role of early childhood education. The level of education of parents have a large influence on children's development. The level of education of parents is positively correlated with the way they care and nurture for children, while parenting is related to child 
development. Thus, the higher the level of education the better the way parents care for their children[4].

Parental involvement program in learning activities in early childhood education is an alternative to increase collaboration between educators and parents to provide a maximum learning process for children. Parental involvement is a process by which parents use all their abilities, for their own benefit, their children, and the programs run for the child themselves[5].

In the Institute for Early Childhood Education SAQO (Kindergarten / Playgroup) Probolinggo, the knowledge of parents about the quality of parenting through communication in parenting is still very minimal. Therefore, it requires knowledge and approaches to increase the capacity of nowadays parents in nurturing children to actualize an outstanding generation through optimizing early childhood development in the golden age. This study aims to describe the implementation of community service in providing parenting education activities through optimizing the golden age. The activities carried out provide an understanding of strategies in improving the quality of child care through communication in early childhood care, and increasing the role of parents to prepare children as an outstanding generation through optimizing the golden age.

The benefit of conducting parenting education in SAQO Kindegarten-Playgroup Kraksaan, Probolinggi is to 1) enrich the knowledge of parents about the development of early childhood, particularly about rapid early childhood development duirng the children's golden age, 2) Improve the quality of family roles and functions, 3) Increase parental understanding of knowledge about nutrition, harmony and sense of family, and 4) Increase understanding and knowledge about character education. The benefits of parenting education activities are to improve the ability and quality of parents in directing and nurturing their children optimally. An understanding of early childhood education and parenting style approaches, communication and the cultivation of character values for early childhood is expected to be able to increase parents' insight and experience thus they can be applied in families optimally, especially during the golden age.

\section{METHOD}

The method of implementing the parenting education program at SAQO-KB TK was a participatory method, demonstration, and assignment with a share and care approach. Share as a medium to share experiences, problems and approaches in dealing with early childhood problems and provide a stimulus to children's intelligence in a holistic manner, sharing knowledge about early childhood development and care and communication between parents and children. While Care is interpreted as a concern for the problems faced by early childhood to be given solutions or solutions to these problems simultaneously. The method of share and care was carried out casually in discussion chats between presenters, teachers and parents. It aims to establish a good connection between school and parents. Some of the approaches taken were 1). Providing material on early childhood education, namely the goal of early childhood education, 2). The material about parenting education, it is about the importance of early childhood education, 3). Providing an understanding on parentung 4). Cultivating character values in children, 5). Training includes simulation, motivation, and reinforcement of positive behavior.

The following figure is the design of Parenting Education activity conducted in SAQO Kindegarten. It includes the process, facilities, infrastructures, and learning evaluation.

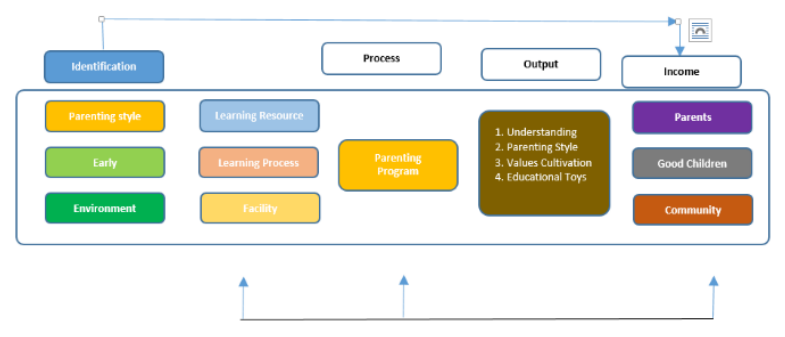

\section{DISCUSSION}

The program conducted was a community service in SAQO Kindegarten/Playgroup Kraksaan, Probolinggo. It was in the form of parenting education which aims at improving the parents' knowledge and quality of parenting by optimizing children's golden age. In addition, this parenting education was intended to improve parents' communication quality during early chilhood parenting process, parents' role in parenting process to actualize outstanding generation, and to cultivate characters education within children during parenting process.

The target of this community service was the parents of 30 students at SAQO Kindegarten/Playgroup Kraksaan, Probolinggo. The approach used in the parenting program at SAQO Kindegarten/Playgroup Kraksaan, Probolinggo was share and care. Share and Care was carried out casually in discussion between presenters, teachers and parents. It aims to establish a good connection between school and parents. The method of implementing the parenting education program at SAQO-KB TK was a participatory method, demonstration, and assignment with a share and care approach. During the activity, several topics were presented as follows:

\subsection{The Importance of Early Childhood Education}

At an early age, children have a tremendous ability to absorb everything around them. Early childhood education is a form of response from research on the golden age of children. This is in accordance with the definition of early childhood education based on Law No. 20 of 2003 which 
states that early childhood education is an effort to provide guidance to children from infant to six years old children through the provision of educational stimuli to support physical and spiritual growth and development, so that children have readiness to enter further education. In addition, early childhood education is very important because early education can develop children's thinking towards school. Children's perception of school and learning depends on the beginning of the education they receive. So, when children have pleasant experiences in early childhood education, the child will have a positive perception of the school.

Whereas, article 28 concerning Early Childhood Education states that early childhood education is held before the level of basic education. Early childhood education can be organized through formal, non-formal, and / or informal education channels. Early Childhood Education as one form of education that focuses on the basis of physical growth and development and intelligence, thinking, creativity, emotions, spiritual, language/communication, and social skills[6].

Early Childhood Education is education which involves all aspects of children[7]. This education covers the physical, cognitive, and social development of children. Learning is organized according to children's interests and learning styles. The aim of early childhood education is to develop various potential children from an early age as a preparation for living and adjusting to their environment. Children's education can also be interpreted as an effort to optimize the extraordinary potential of children that can be developed in education, integrated coaching, and mentoring. Through early childhood education, children will learn about the rules, discipline, introduction of the surrounding world, the growth of good attitudes and behaviors, the ability to communicate and socialize, skills, creativity, and prepare children to pursue the next level of education.

\subsection{Parenting Styles in Family}

The pattern in this context means the arrangement, model, form, procedure, style, in doing something. While parenting in this context means fostering interaction and communication with full attention so that the child grows and develops into an adult person and is able to create a harmonious condition in the family and community environment[8].

Parenting style is the interaction between children and parents in the process of parenting. Parenting in this case allows parents to educate, guide, discipline and protect children to achieve maturity according to the norms that apply in society. As caregivers and mentors in the family, parents play a role in building the basics of behavior for their children. Parents' attitudes, behaviors and habits will always be seen, assessed, and imitated by children. This parent's attitude includes the way parents provide rules, rewards or punishments, how parents show their authority, and how parents provide attention and responses to their children[8]
Based on this understanding, parenting can be interpreted as an illustration of the attitudes and behavior of parents with children in interacting and communicating during parenting activities[8]. Another notion of parenting was put forward by [9] parenting is a method or approach of parenting used by parents so that their children can grow into socially mature individuals. Whereas, according to the guidelines issued by the Family Welfare Empowermentthe notion of parenting is defined as the effort of parents in fostering and guiding children both physically and mentally from birth to adulthood (18 years) [8].

Various types of parenting are divided into three, authoritarian, democratic and permissive parenting [8].

\subsubsection{Authoritarian Parenting}

According to Santrock, the pattern of authoritarian parenting is a style that limits, punishes and requires children to follow all parental orders, respect work and effort. This is similar to what was conveyed that authoritarian parenting is nurturing which provides many prohibitions to children and must be carried out by children without exception[10].

Commonly, parents who apply authoritarian parenting,are rigid, assertive or strict, punishing, lack of love and sympathy. Parents force to obey the values set by parents and try to shape behavior according to the expectation of parents and tend to limit children's passion[8]. Parents do not support and provide opportunities for children to be independent and rarely give praise. Children's rights are restricted but are required to be responsible as adults.

According to some definitions above, Ningrum (2016) suggests several indicators of the authoritarian parenting, such as: giving physical and non-physical punishments, imposing the expectation of parents, setting strict limits, and not providing opportunities for children to speak and express their own ideas.

\subsubsection{Democratic Parenting}

The pattern of democratic parenting is parents who always conduct discussions or deliberations about all actions that must be and will be taken by the children[10]. Democratic parents usually give reasons to approve or disagree with a decision, provide rules that are relatively flexible, and tend to be tolerant. Similarly, Santrock suggests that the pattern of democratic parenting is a style of parents in encouraging children to be independent but still setting boundaries and controlling them.

From the results of their research suggest that democratic parenting foster children's self-esteem and self-confidence and tend to encourage independent actions, encouraging them to be able to make their own decisions[8]. This style of parenting encourages independent behavior and responsibility for children. Democratic parents consider the obligations and rights between parents and children equally. Gradually, parents give responsibility to children 
for everything they do. Several characteristics of democratic parenting. Democratic parents provide opportunities for children to be independent, provide space to develop their internal control, recognize their existence and provide opportunities for children to be involved in decision making[8].

In accordance with some of the opinions above, it can be concluded that the pattern of democratic parenting style promotes freedom for children with understandable limitations and boundaries.States that there are three indicators of democratic parenting style, including: giving children the opportunity to speak, encouraging children to be independent, and giving freedom to children with certain limits and boundaries[8].

\subsubsection{Permissive parenting}

In this kind of parenting style, parents give an absolute freedom to children and allows children to act without any direction from parents. Permissive parenting is a parenting style in which the parents cannot adapt to the environment. Parents tend to give freedom to children without giving control at all[9].

Parents give freedom to children to do everything without any limitation and are very weak in carrying out discipline in children[8]. Permissive parents are less assertive in implementing existing regulations and children are given the free opportunity to do and fulfill their desires[11]. Based on some of these meanings, it can be concluded that the pattern of permissive parenting gives complete freedom to children and promotes lack of control from parents. Therefore, because of the lack of structure and rules in the home, these children never learn limits and can lead to aggressive behavior.

\subsection{Cultivating Character Building in Early Childhood}

Early childhood is the initial period of proper development for education. Educational experts declare that it is the golden age of children. In neuroscience studies, it is stated that the development of nerve cells in the brain of a newborn child reaches $25 \%$. Until the age of 4 years, the development of brain nerve cells reaches $50 \%$, and until the age of 8 years the development reaches $80 \%$, the rest develop until the age of 18 years[12]. The neuroscience study illustrates that the most dominant development of children's intelligence occurs at the age of $0-8$ years. Therefore, these periods must be utilized and optimized as well as possible to cultivate the character values of early childhood.

Character is a quality and habits that are embedded in each individual. Characters, if they are formed, are difficult to remove or change. In the Great Indonesian Dictionary $(\mathrm{KBBI})$, character is a personality, psychological traits, morals, or aspects that distinguishes someone from other peopl. This understanding clarify that the character is closely related to morals or character and can also be interpreted as ethical or moral in behavior.

Characters are values that are identical to positive values (good values, good deeds, good life, and have a good impact on the environment) and are embedded in a person and manifested in behavior. From some of these definitions it can be understood that character is a personality possessed by someone who has become a character or character that is difficult to eliminateor change. Therefore, character is a reflection of daily behavior. This character makes the difference between one person and another[13].

Many character values can be instilled in children from an early age. In the view of character education in Indonesia, there are at least 18 (eighteen) character values that can be inserted in the learning process [13], including:

\subsection{Utilizing Scraps for Educational Toys}

Educational toys are instrument or object of play that can be used as a tools or equipment for playing that contains educational value, and aims at developing all children's abilities. Several aspects must be considered to choose the appropriateducational toys. The use of recycled educational toys in learning is inseparable from the nature of the child in learning something through concrete objects thus learning becomes meaningful to the child. Learning will not be optimal if the school does not provide adequate facilities. This is based on the principle of children's way of learning, learning by using their five senses. For meaningful learning children need educational toys to maximize exploration, discovery, creation, development of thinking. As a results, if educational toys are not available, the teacher must substitute it by utilizing the recycled object as an educational toy.

Through the use of waste or recycled materials, the teacher: [8] creates a new educational toys by utilizing recycled materials and natural materials as a medium of play for children [14] optimize the use of recycled materials as an educational toys or learning resource for children so that the learning environment is more varied [11] knows a variety of recycledmaterials that can be used as an educational toys or learning resource[14].

The environment around us is rich in learning resources. Teachers should be able to use these learning resources as educational toys. Educational toys from recycled materials can be interpreted as scraps in the surrounding environment that can be reused as raw materials in making handicrafts[15].

The recycled materials are recycled paper (magazines, newspapers, paper bags), cardboard or carton, cloth, plastic, cans, foam, ropes, bottle caps, and rubber. First, recycled paper (magazines, newspapers, paper bags) can be used as an educational game to improve language development, fine motor skills, and percussion instruments. Second, cardboard and carton can be used as blocks, boxes to make miniature buildings, storage of small toys, musical instruments, stage puppets, and making patterns. Third, Cain can be used to improve 
[2] F. Nurmalitasari, "Perkembangan Sosial Emosi pada Anak Usia Prasekolah," Bul. Psikol., vol. 23, no. 2, p. 103, 2015. used to improve fine motor skills. Fifth, Plastics and cans can be used to make hand puppets, communication devices, musical instruments, and for measuring activities when playing sand and water. Sixth, bottle caps and rubber are used for the development of mathematics, musical instruments, forming with bottle caps and rubber. Seventh, plastic rope, raffia, wool can be used to sew cardboard boards, plywood boards, paint, and stamp[14]

The use of educational toys from recycled materials in early learning is able to promote an understanding and awareness about environmental preservation. As a results, a presevred and safe environment will be achieved for all living things. The habit of recycling materials coupled with high creativity in the use of educational toys from recycled materials will help children and society to improve their standard of living.

\section{CONCLUSION}

During the learning process to evaluation, parents understand the importance of parenting programs for child development, 1). The community understands the importance of parenting styles for early childhood. While, the supporting factors are 2). the availability of facilities and infrastructure that can be used by presenters to deliver parenting programs to parents, 3). Parents were enthusiastic about participating in the program activities provided by Tim. This was indicated by the number of the attendance. 4). During the delivery of the material, there were many parents who were active and responsive in responding to questions and giving questions to the presenter, 4). Parents expect that the team can provide further material on the upcoming opportunities.

\section{ACKNOWLEDGMENT}

The authors express their greatest gratitude to the Department, Faculty, and University as institution who support the program, particularly Faculty of Educational Science which provide us a great opportunity to conduct community service and research in SAQO Kindegarten, Kraksaan Probolinggo.

\section{REFERENCES}

[1] E. Martsiswati and Y. Suryono, "Peran Orang Tua dan Pendidik dalam Menerapkan Perilaku Disiplin terhadap Anak Usia Dini," J. Pendidik. dan Pemberdaya. Masy., vol. 1, no. 2, pp. 187-198, 2014.
[3] F. Hayati and N. Mamat, "Pengasuhan dan Peran Orang Tua (Parenting) serta Pengaruhnya terhadap Perkembangan Sosial Emosional Anak di PAUD Banda Aceh, Indonesia," buah hati, vol. I, no. 1, pp. 16-30, 2014.

[4] W. Sulistyaningsih, "Kesiapan Bersekolah Ditinjau dari Jenis Pendidikan Prasekolah Anak dan Tingkat Pendidikan Orang Tua," Psikologia, vol. 1, no. 1, pp. 1-8, 2005.

[5] Patmonodewo and Soemiarti, Pendidikan anak prasekolah. Jakarta: Rineka Cipta, 2000.

[6] M. Hasan, Pendidikan Anak Usia Dini (PAUD). Yogyakarta: Diva Press, 2009.

[7] J. W. Santrock, Child Psychology. Boston: McGrawHill, 2001.

[8] M. A. Ningrum, Pola Pengasuhan Anak Usia Dini. Surabaya: Unesa University Press, 2016.

[9] J. W. Santrock, Psikologi Pendidikan. Jakarta: Salemba, 2013.

[10] W. . Gerungan, Psikologi Sosial. Bandung: Refika Aditama, 2004.

[11] I. Barnadib, Filsafat Pendidikan: Tinjauan Mengenai Beberapa Aspek dan Proses Pendidikan. Yogyakarta: Andi Offset, 1986.

[12] E. Mulyasa, Praktik Penelitian Tindakan Kelas. Bandung: PT Remaja Rosdakarya, 2009.

[13] M.Fadlillah, "Penanaman Nilai=nilai Karakter Anak Usia Dini melalui Permainan-permainan Edukatif," in Prosiding Seminar Nasional dan Call for Paper ke-2 "Pengintegrasian Nilai Karakter dalam Pembelajaran Kreatif di Era Masyarakat Ekonomi ASEAN," 2016, vol. 2.

[14] L. Asmawati, Perencanaan pembelajaran PAUD. Bandung: Remaja Rosdakarya, 2014.

[15] Y. Nurani, "Perkembangan Media Daur Ulang Berbasis Kecerdasan Jamak dalam Peningkatan Keterampilan Hidup Anak Usia Dini," Cakrawala Pendidik., no. 1, pp. 67-81, 2012. 